УДК 615.01:615.454.2: 612.94.017.1

DOI https://doi.org/10.11603/2312-0967.2020.1.10979

\title{
УДОСКОНАЛЕННЯ СКЛАДУ І РОЗРОБКА ЕКСТЕМПОРАЛЬНОЇ ТЕХНОЛОГІЇ ПЕСАРІЇВ ІЗ ДОКСИЦИКЛІНОМ ХІКЛАТОМ НА ОСНОВІ МАСЛА КАКАО
}

\author{
В. М. Чушенко, Т. Г. Ярних, О. А. Рухмакова, Г. Б. Юр'єва \\ Національний фрармацевтичний університет, Харків \\ rukhmakovaolga@gmail.com
}

ІНФОРМАЦІЯ

Надійшла до редакції / Received: 13.02.2020

Після доопрацювання / Revised: 20.02.2020

Прийнято до друку / Accepted: 24.02.2020

\section{Ключові слова:}

песарії;

склад;

доксицикліну хіклат;

масло какао;

екстемпоральна технологія.
АНОТАЦІЯ

Мета роботи. Удосконалення складу і розробка екстемпоральної технології песаріїв із доксицикліном хіклатом на основі масла какао.

Матеріали і методи. Встановлено, що рецептурні прописи для лікування вагінальних інфеекцій досить часто представлені песаріями із доксицикліну хіклатом на поліетиленоксидній основі. 3 метою їх удосконалення до складу лікарського засобу, окрім доксицикліну хіклату, введено лінімент синтоміцину, димексид і ментол. Як супозиторну основу використано суміш масла какао із воском бджолиним. Приготування песаріїв здійснено методом виливання 3 урахуванням вимог ДФУ 2.0 і Настанови МОзУ «Вимоги до виготовлення нестерильних лікарських засобів в умовах аптек». Для визначення срармакотехнологічних показників модельних зразків лікарського засобу вивчено їх опис (однорідність), температуру плавлення і стійкість до руйнування.

Результати й обговорення. 3 метоювизначення оптимального співвідношення масла какао і воску бджолиного у складі супозиторної основи досліджено фрармакотехнологічні показники їх модельних зразків. Для подальших досліджень обрано співвідношення компонентів 92,5:7,5 і 95,0:5,0. При вивченні впливу емульгаторів (емульгатор Т-2, лецитин) на деякі показники якості песаріїв встановлено, що лише зразки лікарського засобу на обраній супозиторній основі у співвідношенні 95,0:5,0 із вмістом лецитину в кількості 2-3 \% відповідають вимогам ДФУ за показниками «Опис» і «Температура плавлення». Експериментально доведено, що доксицикліну хіклат легко змішується з лініментом синтоміцину, що сприяє його рівномірному розподілу в супозиторній основі. Такий спосіб введення антибіотика значно покращує якість отриманих песаріїв (відсутній ефект осідання).

При розробці екстемпоральної технології лікарського засобу методом виливання визначено зворотний коефіцієнт заміщення доксицикліну хіклату на маслі какао, який становить 0,81. Зразки песаріїв, виготовлені за запропонованою технологією, проаналізовано за показниками якості відповідно до вимог ДФУ 2.0, чинних наказів, інструкцій і настанов МОЗ України. Висновки. Проведено експериментальні дослідження з удосконалення складу екстемпоральних песаріїв із доксицикліном хіклатом для лікування інсеекційного вагініту. До складу лікарського засобу, окрім доксицикліну хіклату, введено лінімент синтоміцину, димексид і ментол. Як супозиторну основу використано суміш масла какао і воску бджолиного у співвідношенні 95,0:5,0. Розроблено екстемпоральну технологію песаріїв методом виливання. Показано, що отримані зразки песаріїв повністю відповідають вимогам ДФУ до даної лікарської фрорми.

ISSN 2312-0967. Pharmaceutical review. 2020. № 1 
Фармацевтична технологія, біофармація, гомеопатія Pharmaceutical technology, biopharmacy, homeopathy

Вступ. Серед захворювань жіночих статевих органів запальні процеси посідають перше місце за частотою та зустрічаються у 60-65 \% гінекологічних хворих. За останнє десятиріччя серед жінок багатьох країн спостерігається збільшення інфекцій піхви, які посідають перше місце в структурі акушерсько-гінекологічних захворювань. Бактеріальні інфекції піхви $€$ найбільш поширеними захворюваннями, які зустрічаються у гінекологічній практиці. Їх частота в різних популяціях коливається в межах від 30 до 80 \%.

Серед інфекційних захворювань найпоширенішими є дисбіози (бактеріальний вагіноз, урогенітальний кандидоз), хламідіоз і трихомоніаз [1]. Інфекційно-запальні гінекологічні захворювання жіночих статевих органів посідають особливе місце в структурі загальної захворюваності у світі. Їх значущість зумовлена насамперед тим, що всі ці захворювання уражають органи і тканини репродуктивної системи.

Головними причинами інсрекційного вагініту $€$ вульвовагінальний кандидоз, трихомоніаз і бактеріальний вагіноз. Кожен із цих розладів може спричиняти неприємні вагінальні симптоми, а два останні ще й ускладнення 3 боку верхніх репродуктивних шляхів. Таким чином, необхідність подальшого вивчення проблеми вагінальних інфекцій є актуальною. Послідовне вирішення цієї проблеми буде сприяти поліпшенню репродуктивного здоров'я та якості життя жінок [2]

Вагінальні лікарські засоби мають важливе значення і широко використовуються в комплексній терапії змішаних урогенітальних інфекцій. Підвищення місцевого впливу на осередок ураження досягається завдяки використанню лікарських фрорм місцевої дії. 3 них найбільш ефективними у гінекологічній практиці є песарії або вагінальні супозиторії $[1,2]$.

На сьогодні виготовлення ліків в умовах аптек не втрачає значення. Екстемпоральне виробництво лікарських засобів робить можливим індивідуальний підхід до пацієнтів, який дозволяє врахувати особливості організму, перебіг хвороби, симптоматику захворювання і його стадію. Це є головним принципом і перевагою виготовлення лікарських засобів «ех tempore».

Мета роботи - удосконалення складу і розробка екстемпоральної технології песаріїв із доксицикліном хіклатом на основі масла какао.

Матеріали і методи. Розробку технології песаріїв для лікування вагінальних інфекцій здійснювали 3 урахуванням вимог Державної фрармакопеї України 2.0 і Настанови МОЗУ «Вимоги до виготовлення нестерильних лікарських засобів в умовах аптек» [3, 4, 5].

При створенні вагінальних лікарських засобів, крім вибору відповідних активних фрармацевтичних інгредієнтів, особливе значення приділяється змінним фрармацевтичним чинникам - природі основи-носія та виду лікарської фрорми. На міжнародному фрарма- цевтичному ринку представлені супозиторні основи різного характеру. Найбільш широко використовуваними супозиторними основами у промисловості $€$ вітепсол і поліетиленоксид [6].

Проаналізувавши рецептурні прописи для лікування вагінальних інсрекцій, встановлено, що лікарі м. Харкова найчастіше виписують рецепти, до складу яких входить доксицикліну хіклат, а як основу використовують поліетиленоксидну основу. Однак ця основа синтетичного походження, у пацієнтів може спричиняти неприємні відчуття або алергічні реакції, оскільки має великий осмос.

В екстемпоральній рецептурі найчастіше використовують основу - масло какао - природного походження, яка не має вказаних вище недоліків при застосуванні. Масло какао належить до природних гідрофробних основ і протягом багатьох років $€$ найкращою основою природного походження. Масло какао має ряд переваг: добре змішується з різними лікарськими речовинами, швидко вивільняє введені лікарські речовини, має чітко виражену температуру плавлення та високу пластичність, а також має виражену репаративну та змащувальну дію.

3 метою вибору раціонального носія ми вивчили основу, розроблену на кафедрі технології ліків Національного фрармацевтичного університету під керівництвом профр. Т. Г. Ярних і доц. В. М. Чушенко (патент на корисну модель № 69000) [7]. До складу цієї основи входять масло какао та віск бджолиний, основу готують методом виливання.

Після консультацій 3 лікарями-гінекологами м. Харкова пропонується до складу песаріїв для лікування вагінальних інфекцій, крім доксицикліну хіклату, ввести ще й лінімент синтоміцину, димексид і ментол.

Лінімент синтоміцину застосовується як антибіотик для місцевого лікування таких бактеріально-інфрекційних хвороб, як вагініт та цервіцит.

Димексид проявляє антибактеріальні, протизапальні та легкі анестезуючі властивості і входить в схеми лікування інфекційно-запальних захворювань зовнішніх жіночих статевих органів, піхви і шийки матки (при вульвовагінітах, цервіцитах) будь-якого походження (бактеріального, грибкового, вірусного, спричиненого найпростішими) підсилюючи ефект інших лікарських препаратів, зокрема антибіотиків. Розчини димексиду використовують у вигляді вагінальних тампонів, у деяких випадках гінекологи призначають одночасне поєднання димексиду і антибіотика в одному тампоні.

Ментол чинить місцевоподразнювальну, аналгезуючу, відволікаючу, протисвербіжну, антисептичну, заспокійливу дію, надаючи відчуття прохолоди, сприяє кращому проникненню діючих речовин.

Доксицикліну хіклат є антибактеріальним засобом системного застосовування класу тетрациклінів. Чинить бактеріостатичну дію за рахунок пригнічення

ISSN 2312-0967. Фармацевтичний часопис. 2020. № 1 
синтезу білка збудників у результаті блокування зв'язку аміноацил-транспортної РНК (ТРНК) із комплексом «інфрормаційна РНК (іРНК) - рибосома». Доксициклін активний щодо грампозитивних і грамнегативних бактерій. Він швидко всмоктується із травного тракту, практично незалежно від прийому їжі. Зв'язується із білками плазми крові на 80-90 \%. Максимальна концентрація у плазмі крові досягається через 2 год після приймання лікарського засобу. Залежно від дози терапевтична концентрація доксицикліну в крові зберігається протягом 18-24 год. Швидко розподіляється у більшість рідин організму, включно жовч, секрет навколоносових пазух, плевральну, синовіальну та асцитичну рідини. Концентрація у спинномозковій рідині змінюється і після парентерального застосування може становити 10-25 \% від концентрації у сироватці крові. Виводиться із організму повільно. Період напіввиведення лікарського засобу - 12-22 год. Значна частина доксицикліну виводиться у незміненому вигляді 3 фекаліями, приблизно $40 \%$ із сечею $[8,9]$.

Вивчивши фрізико-хімічні властивості лікарських речовин, які пропонується ввести до складу песаріїв, було встановлено, що такі речовини, як димексид та ментол розчинні у гідрофобних основах, тому їх введення в масло какао не викликає труднощів; а введення доксицикліну хіклату, не розчинного у гідрофообній основі, потребує введення допоміжних речовин.

Саме тому до складу основи, крім масла какао, було введено й віск бджолиний. Віск бджолиний та-
Фармацевтична технологія, біофармація, гомеопатія Pharmaceutical technology, biopharmacy, homeopathy

кож належить до класу природних гідросробних основ. Якісний склад воску бджолиного зумовлює його помірні протизапальні, репаративні та місцевоанестезуючі властивості.

Таким чином, запропонована супозиторна основа складається із масла какао та воску бджолиного при співвідношенні компонентів (маса, \%):

масло какао - 92,5-99,0

віск бджолиний - до 100,0.

Результати й обговорення. 3 метою визначення співвідношення масла какао і воску бджолиного для приготування супозиторіїв із доксицикліном ми виготовили модельні зразки основи у різних співвідношеннях. Результати експерименту представлені в таблиці 1.

За даними таблиці 1, основа № 3 у співвідношенні масло какао-віск бджолиний (97,5 \% : 2,5 \%) не підходить для виготовлення песаріїв через низьку температуру плавлення - 32,1 ${ }^{\circ} \mathrm{C}$. Тому для подальшого експерименту зупинилися на основах № 1 та № 2 .

На наступному етапі досліджень визначено вплив емульгаторів на фрармакотехнологічні показники супозиторіїв. Емульгатори додавали для змішування гідрофобної та гідрофільної фраз песаріїв.

Як емульгатори використовували лецитин і емульгатор Т-2. Це ліпофрільні емульгатори із ГЛБ 3-6, типу вода-олія. Емульгатор Т-2 підігрівали до розплавлення, змішували з сумішшю подрібненого доксицикліну хіклату з водою, лініментом і димексидом, а потім із розплавленою основою (віск, масло какао), до якої вводили ментол (табл. 2).

\section{Таблиця 1}

Показники якості модельних зразків основи: масло какао-віск бджолиний

\begin{tabular}{|c|c|c|c|c|c|}
\hline \multirow[b]{2}{*}{ № } & \multirow{2}{*}{$\begin{array}{c}\text { Масло } \\
\text { какао, \% }\end{array}$} & \multirow{2}{*}{$\begin{array}{c}\text { Віск бджолиний, } \\
\%\end{array}$} & \multicolumn{3}{|c|}{ Показники якості } \\
\hline & & & Опис & $\begin{array}{l}\text { Температура } \\
\text { плавлення, }{ }^{\circ} \mathrm{C}\end{array}$ & $\begin{array}{c}\text { Стійкість до } \\
\text { руйнування, кг }\end{array}$ \\
\hline 1 & 92,5 & 7,5 & $\begin{array}{c}\text { Основа однорідна, біло- } \\
\text { жовтуватого кольору }\end{array}$ & 36,8 & 1,4 \\
\hline 2 & 95,0 & 5,0 & $\begin{array}{c}\text { Основа однорідна, біло- } \\
\text { жовтуватого кольору }\end{array}$ & 34,5 & 1,2 \\
\hline 3 & 97,5 & 2,5 & $\begin{array}{c}\text { Основа однорідна, біло- } \\
\text { жовтуватого кольору }\end{array}$ & 32,1 & 0,9 \\
\hline
\end{tabular}

\section{Таблиця 2}

Показники якості зразків песаріїв із доксицикліну хіклатом, виготовлених із додаванням емульгатора Т-2

\begin{tabular}{|c|c|c|c|c|}
\hline № & $\begin{array}{c}\text { Співвідношення масло какао : } \\
\text { віск бджолиний, \% }\end{array}$ & $\begin{array}{c}\text { Кіль- } \\
\text { кість емульгатора, } \%\end{array}$ & Опис & $\begin{array}{c}\text { Температура } \\
\text { плавлення, }{ }^{\circ} \mathrm{C}\end{array}$ \\
\hline \multirow{3}{*}{1} & $92,5: 7,5$ & 1 & Неоднорідні & - \\
& & 2 & Однорідні & 37,9 \\
\hline \multirow{2}{*}{2} & $95,0: 5,0$ & 3 & Однорідні & 37,8 \\
& & 2 & Неоднорідні & Однорідні \\
\hline
\end{tabular}

ISSN 2312-0967. Pharmaceutical review. 2020. № 1 
Фармацевтична технологія, біофармація, гомеопатія Pharmaceutical technology, biopharmacy, homeopathy

Лецитин замочували у воді очищеній, підігрітій до $30 \pm 1{ }^{\circ} \mathrm{C}$ протягом 20 хв до одержання однорідної емульсії, змішували 3 подрібненим доксицикліну хіклатом, лініментом і димексидом, а потім із розплавленою основою (віск, масло какао), до якої вводили ментол (табл. 3). вміст діючих речовин у песарії складає більше 5 \%, то необхідно знайти точне співвідношення між об'ємом, що займають діючі речовини та основа. Це співвідношення виражають «коефріцієнтом заміщення» або «зворотним коефріцієнтом заміщення» [10]. Згідно з даними експерименту зворотний коефіцієнт

Таблиця 3

Показники якості зразків песаріїв із доксицикліну хіклатом, виготовлених із додаванням лецитину

\begin{tabular}{|c|c|c|c|c|}
\hline \multirow{2}{*}{$№$} & $\begin{array}{c}\text { Спів відношення масло } \\
\text { какао : віск бджолиний, \% }\end{array}$ & $\begin{array}{c}\text { Кількість емульгатора, } \\
\%\end{array}$ & Опис & $\begin{array}{c}\text { Температура плавлення, } \\
{ }^{\circ} \mathrm{C}\end{array}$ \\
\hline \multirow{3}{*}{1} & $92.5: 7.5$ & 1 & Неоднорідні & - \\
& & 2 & Однорідні & 37,8 \\
\hline \multirow{2}{*}{2} & $95,0: 5,0$ & 3 & Однорідні & 37,5 \\
& & 2 & Неоднорідні & Однорідні \\
\hline
\end{tabular}

Для визначення фрармакотехнологічних показників модельних зразків вивчали їх опис (однорідність) та температуру плавлення.

За даними таблиці 2, песарії з доксицикліном хіклатом, виготовлені на основі масло какао : віск бджолиний у співвідношенні $(92,5: 7,5)$ й у співвідношенні $(95,0: 5,0)$ із додаванням емульгатора Т-2 у кількості 1, 2, 3 \%, не відповідають вимогам ДФУ 2.0 за показниками «Опис» та «Температура плавлення».

За даними таблиці 3, зразки супозиторіїв із доксицикліну хіклатом, виготовлені на основі масло какао : віск бджолиний у співвідношенні $(92,5: 7,5)$ і додаванням емульгатора лецитину в кількості 1 , $2,3 \%$ та у співвідношенні $(95,0: 5,0)$ та кількості емульгатору 1 \% також не відповідають вимогам ДФУ 2.0 за показниками «Опис» та «Температура плавлення».

Лише зразки песаріїв на основі масла какао у співвідношенні $(95,0: 5,0)$ із вмістом емульгатора лецитину у кількості 2-3 \% відповідають вимогам ДФУ 2.0 за показниками «Опис» та «Температура плавлення». Таким чином, проведені дослідження показали, що до складу супозиторіїв необхідно вводити як емульгатор - лецитин у кількості 2-3\%.

Відомо, що доксицикліну хіклат легко розчиняється у воді очищеній. Експериментально ми досліджували змішуваність доксицикліну хіклату з лініментом синтоміцину. Встановлено, що доксицикліну хіклат легко змішується 3 лініментом синтоміцину, що сприяє його рівномірному розподілу у супозиторній основі. Такий спосіб введення антибіотика значно покращує якість отриманих песаріїв (відсутній ефект осідання).

При приготуванні супозиторіїв методом виливання слід враховувати, що їх маса залежить від розміру чарунок, густини діючих речовин і основи. Якщо заміщення доксицикліну на маслі какао становить 0,81 .

Технологія виготовлення екстемпоральних песаріїв із доксицикліну хіклатом на основі масла какао методом виливання полягає у наступному: зразки песаріїв готують в асептичних умовах (ламінарний бокс) шляхом подрібнення доксицикліну хіклату у ступці протягом 3 хв, додають лінімент синтоміцину $10 \%$, розтирають до отримання однорідної суміші; додають димексид та змішують (суміш 1).

У фарфоровій чашці на водяній бані розплавляють віск бджолиний, охолоджують до $(40,0 \pm 2,5){ }^{\circ} \mathrm{C}$, потім додають масло какао, знімають $з$ водяної бані, додають ментол, перемішують (основа).

Лецитин замочують у воді очищеній, підігрітій до $(30 \pm 1){ }^{\circ} \mathrm{C}$ протягом 20 хв до одержання однорідної емульсії, змішують із сумішшю 1 , потім із основою. Ретельно перемішують напівохолоджену масу. Швидко розливають у попередньо змащену мильним спиртом і охолоджену фрорму, поміщають у холодильник на 20-30 хв.

Склад діючих речовин на один песарій, г:

Doxycyclini hyclatis 0,100

Linimenti synthomycini $10 \% 0,250$

Dimexidi 0,020

Mentholi 0,010

Lecithini 0,15

Aquae purificatae gtts. $X$

Olei Cacao:Cerae flavi (95:5) ad 3,0

Зразки запропонованих вагінальних супозиторіїв (песаріїв) були проаналізовані за показниками відповідно до вимог ДФУ 2.0, чинних наказів, інструкцій МОЗ України та методичних рекомендацій $[1,2,4]$

Результати досліджень представлені в таблиці 4.

ISSN 2312-0967. Фармацевтичний часопис. 2020. № 1 
Фармацевтична технологія, біофармація, гомеопатія Pharmaceutical technology, biopharmacy, homeopathy

Таблиця 4

Показники якості песаріїв із доксицикліном хіклатом, виготовлених методом виливання

\begin{tabular}{|l|l|l|}
\hline \multicolumn{1}{|c|}{ Найменування показника } & \multicolumn{1}{|c|}{ Допустимі межі } & \multicolumn{1}{|c|}{ Результати дослідження } \\
\hline Опис & $\begin{array}{l}\text { Песарії тверді, однодозові, біло-жовтого } \\
\text { кольору, зі специсічним запахом }\end{array}$ & $\begin{array}{l}\text { Песарії тверді, однодозові, біло-жовтого } \\
\text { кольору, зі специфічним запахом }\end{array}$ \\
\hline Однорідність & $\begin{array}{l}\text { На повздовжньому зрізі повинні бути } \\
\text { відсутніми вкраплення. } \\
\text { Допускається наявність повітряного } \\
\text { стрижня }\end{array}$ & $\begin{array}{l}\text { На повздовжньому зрізі відсутні } \\
\text { вкраплення. Наявний } \\
\text { повітряний стрижень }\end{array}$ \\
\hline Середня маса, г & Від 2,85 до 3,15 & 2,95 \\
\hline Час розпадання, хв & Не більше 30 & 14 \\
\hline Температура плавлення, ${ }^{\circ} \mathrm{C}$ & Не вище 37 & 36,6 \\
\hline
\end{tabular}

Висновки. Проведено експериментальні дослідження із удосконалення складу і розробки технології екстемпоральних песаріїв із доксицикліном хіклатом на природній основі (масло какао) для лікування інорекційного вагініту.

До складу песаріїв, окрім доксицикліну хіклату, введено лінімент синтоміцину, димексид і ментол. Як супозиторну основу використано суміш масла какао і воску бджолиного у співвідношенні 95,0 : 5,0.
Запропоновано екстемпоральну технологію виготовлення песаріїв методом виливання. Показано, що виготовлені зразки вагінальних супозиторіїв за розробленою технологію повністю відповідають вимогам ДФУ до даної лікарської фороми.

Конфлікт інтересів: відсутній.

Conflicts of interest: authors have no conflict of interest to declare.

\section{IMPROVEMENT OF THE COMPOSITION AND DEVELOPMENT OF THE EXTEMPORANEOUS TECHNOLOGY OF PESSARIES WITH DOXYCYCLINE HYCLATE BASED ON COCOA BUTTER}

\section{M. Chushenko, T. G. Yarnykh, O. A. Rukhmakova, G. B. Yuryeva}

National University of Pharmacy, Kharkiv

rukhmakovaolga@gmail.com

The aim of the work. To improve the composition and develop of the extemporaneous technology of pessaries with doxycycline hyclate based on cocoa butter.

Materials and Methods. Extemporaneous prescriptions for the treatment of vaginal infections have been found to be often represented by polyethylene oxide-based pessaries with doxycycline hyclate. In order to improve them, in addition to doxycycline hyclate, liniment of syntomycin, dimexide and menthol were introduced in their composition. The cocoa butter mixture with beeswax was used as suppository base. The preparation of the pessaries was performed by the method of pouring out, taking into account the requirements of the State Pharmacopoeia of Ukraine 2.0 and the Instruction of the Ministry of Health of Ukraine "Requirements for the preparation of non-sterile medicines in the conditions of pharmacies". To determine the pharmacotechnological parameters of model samples of the medicine, their description (homogeneity), melting point and resistance to destruction were studied.

Results and Discussion. To determine the optimal ratio of cocoa butter and beeswax in the composition of the suppository base, the pharmacotechnological parameters of their model samples were investigated. Components ratios 92.5:7.5 and 95.0:5.0 were selected for further studies. When studying the effect of emulsifiers (emulsifier T-2, lecithin) on some indicators of the quality of pessaries, it was found that only samples of the medicine on the selected suppository base in the ratio of 95.0:5.0 with a content of lecithin in the amount of 2-3\% meet the requirements of SPU in terms of "Description" and "Melting point".

It has been experimentally proven that doxycycline hyclate is mixable with the liniment of syntomycin and glycerol, which promotes its even distribution in the suppository base and improves the quality of pessaries (no sedimentation effect).

In the development of extemporaneous technology of the medicine by the method of pouring is determined the inverse coefficient of substitution of doxycycline hyclate in cocoa butter, which is 0.81 . The samples of the pessaries prepared according to the proposed technology were analyzed according to the quality indicators in accordance with the requirements of SPU 2.0, current orders, instructions and guidelines of the Ministry of Health of Ukraine.

Conclusions. Experimental studies have been conducted to improve the composition of extemporaneous pessaries with doxycycline hyclate for the treatment of infectious vaginitis. In addition to doxycycline hyclate, the liniment of syntomycin,

ISSN 2312-0967. Pharmaceutical review. 2020. № 1 
Фармацевтична технологія, біофармація, гомеопатія

Pharmaceutical technology, biopharmacy, homeopathy

dimexide and menthol was introduced into the medicine. As a suppository base used a mixture of cocoa butter and beeswax in a ratio of 95.0:5.0. Extemporaneous technology of pessaries by pouring method has been developed. It is shown that the obtained samples of pessaries fully meet the requirements of the SPU to this dosage form.

Key words: pessaries; composition; doxycycline hyclate; cocoa butter; extemporaneous technology.

\title{
УСОВЕРШЕНСТВОВАНИЕ СОСТАВА И РАЗРАБОТКА ЭКСТЕМПОРАЛЬНОЙ ТЕХНОЛОГИИ ПЕССАРИЕВ С ДОКСИЦИКЛИНОМ ХИКЛАТОМ НА ОСНОВЕ МАСЛА КАКАО
}

\author{
В. М. Чушенко, Т. Г. Ярных, О. А. Рухмакова, А. Б. Юрьева \\ Национальный фрармацевтический университет, Харьков \\ rukhmakovaolga@gmail.com
}

Цель работы. Усовершенствование состава и разработка экстемпоральной технологии пессариев с доксициклином хиклатом на основе масла какао.

Материалы и методы. Установлено, что рецептурные прописи для лечения вагинальных иноееций достаточно часто представлены пессариями с доксициклином хиклатом на полиэтиленоксидной основе. С целью их усовершенствования в состав лекарственного средства, кроме доксициклина хиклата, введены линимент синтомицина, димексид и ментол. В качестве суппозиторной основы использована смесь масла какао с воском пчелиным. Приготовление пессариев осуществлено методом выливания с учетом требований ГФУ 2.0 и стандарта М3 Украины «Требования к приготовлению нестерильных лекарственных средств в условиях аптек». Для определения фрармакотехнологических показателей модельных образцов лекарственного средства изучено их описание (однородность), температуру плавления и стойкость к разрушению.

Результаты и обсуждение. С целью определения оптимального соотношения масла какао и воска пчелиного в составе суппозиторной основы исследованы фрармакотехнологические показатели их модельных образцов. Для дальнейших исследований выбрано соотношение компонентов 92,5:7,5 и 95,0:5,0. При изучении влияния эмульгаторов (эмульгатор Т-2, лецитин) на некоторые показатели качества пессариев установлено, что только образцы препарата на выбранной суппозиторной основе в соотношении 95,0:5,0 с содержанием лецитина в количестве 2-3 \% соответствуют требованиям ГФУ по показателям «Описание» и «Температура плавления».

Экспериментально доказано, что доксициклина хиклат легко смешивается с линиментом синтомицина, что способствует его равномерному распределению в суппозиторной основе. Такой способ введения антибиотика значительно улучшает качество полученных пессариев (отсутствует эффект оседания).

При разработке экстемпоральной технологии лекарственного средства методом выливания определен обратный коэффрициент замещения доксициклина хиклата на масле какао, который составляет 0,81. Образцы пессариев, приготовленные по предложенной технологии, проанализированы по показателям качества в соответствии с требованиями ГФУ 2.0, действующих приказов, инструкций и стандартов МОЗ Украины.

Выводы. Проведены экспериментальные исследования по усовершенствованию состава экстемпоральных пессариев с доксициклином хиклатом для лечения иноекционного вагинита. В состав лекарственного средства, кроме доксициклина хиклата, введены линимент синтомицина, димексид и ментол. В качестве суппозиторной основы использована смесь масла какао и воска пчелиного в соотношении 95,0:5,0. Разработана экстемпоральная технология пессариев методом выливания. Показано, что полученные образцы пессариев полностью соответствуют требованиям ГФУ к данной лекарственной фрорме.

Ключевые слова: пессарии; состав; доксициклина хиклат; масло какао; экстемпоральная технология.

\section{Список бібліографічних посилань}

1. ОрловаТ.В.Современные ректальные, вагинальные и уретральные лекарственные формы. Вестник ВГУ. Сер. Химия. Биология. Фармация. 2014. № 1. C. $126-133$.

2. Панкрушева Т. А., Бредихина Т. А., Медведева О. А. Исследования по разработке интравагинальных суппозиториев с азитромицином для лечения урогенитальных инфекционных заболеваний. Забайкальский медицинский вестник. 2011. № 2. С. 146155.
3. Державна Фармакопея України : в 3 т. / ДП Український науковий фрармакопейний центр якості лікарських засобів. 2-е вид. Харків : Державне підприємство «Український науковий фрармакопейний центр якості лікарських засобів», 2015. T. 1. 1128 c.

4. Державна Фармакопея України : Супозиторії та песарії, виготовлені в аптеках / ДП «Науковоекспертний фрармакопейний центр». 2 вид. Х. : РІРЕГ, 2014. С. 716-723.

ISSN 2312-0967. Фармацевтичний часопис. 2020. № 1 
5. Настанова СТ-Н МОЗУ 42-4.5:2015. Вимоги до виготовлення нестерильних лікарських засобів в умовах аптек. Київ. МОЗ України. 2015. 109 С.

6. Орлова Т. В., Панкрушева Т. А. Выбор суппозиторной основы в технологии суппозиториев. Фармация. 2014. № 1. С. 34-38.

7. Ярних Т. Г., Чушенко В. М., Толочко К. В. Основа для супозиторіїв : пат. № 69000. № u201107727 ; опубл. 25.04.2012, Бюл. № 8.

8. Козлов Р. С., Голуб А. В. Место доксициклина в современной клинической практике. Медицинский совет. 2014. № 9. С. 118-124.

9. Doxycycline in the treatment of rheumatoid arthritis - a pilot study. Sreekanth W. R., Handa R., Aggarwal P. et al. Assoc. Physicians India. 2000. Vol. 48 (8). P. 804-807.

10. Ярных Т. Г., Мельник Г. Н., Рухмакова О. А. Технология приготовления детских суппозиториев с экстрактами солодкового корня. Научные ведомости Белгу. Сер. Медицина. Фармация. 2013. № 11(154). C. 258-261.

Pharmacopoeial Center for Medicinal Products Quality; 2015. Ukrainian.

5. Requirements for the manufacture of non-sterile drugs in pharmacies. Guideline of the Health Ministry of Ukraine. State standard as the 42-4.5: 2015. Kyiv: MOZ Ukrainy; 2016. Ukrainian.

6. Orlova TV, Pankrusheva TA [The choice of suppository base in suppository technology]. Farmatsiya. 2014;1: 34-8. Russian.

7. Yarnykh TG, Chushenko VM, Tolochko KV, inventors; National University of Pharmacy, assignee. (Patent) U201107727. 2012 Apr 25. Ukrainian.

8. Kozlov RS, Golub AV [The place of doxycycline in modern clinical practice]. Med. sovet. 2014;9: 118-24. Russian.

9. Sreekanth WR, Handa R, Aggarwal P, et al. Doxycycline in the treatment of rheumatoid arthritis - a pilot study. Assoc. Physicians India. 2000;48(8): 804-7.

10. Yarnykh TG., Melnik GN., Ruhmakova OA. [Technology for the preparation of children's suppositories with liquorice root extracts]. Nauch. vedom. BelGU. Ser. Meditsina. Farmatsiya. 2013;11(154): 258-61. Russian.

\section{Відомості про авторів}

Чушенко В. М. - канд. фрармац. Н., доцент кафедри технології ліків, Національний фрармацевтичний університет, Харків, Україна. E-mail: tI@nuph.edu.ua, ORCID: 0000-0002-1032-9008

Ярних Т. Г. - д. фрармац. Н., профресор, завідувач кафредри технології ліків, Національний фрармацевтичний університет, Харків, Україна. E-mail: t1@nuph.edu.ua, ORCID: 0000-0001-8496-1578

Рухмакова О. А. - д. фрармац. н., доцент кафедри технології ліків, Національний фрармацевтичний університет, Харків, Україна. E-mail: rukhmakovaolga@gmail.com, ORCID: 0000-0002-8573-8965

Юр'єва Г. Б. - канд. фрармац. н., доцент кафедри технології ліків, Національний фрармацевтичний університет, Харків, Україна. E-mail: tl@nuph.edu.ua, ORCID: 0000-0001-9719-2122

\section{Information about the authors}

Chushenko V. M. - PhD (Pharmacy), Associate Professor of the Technology of Drugs Department, National University of Pharmacy, Kharkiv, Ukraine. E-mail: tI@nuph.edu.ua, ORCID: 0000-0002-1032-9008

Yarnykh T. G. - DS (Pharmacy), Professor, Chief of the Technology of Drugs Department, National University of Pharmacy, Kharkiv, Ukraine. E-mail: tI@nuph.edu.ua, ORCID: 0000-0001-8496-1578

Rukhmakova O. A. - DS (Pharmacy), Associate Professor of the Technology of Drugs Department, National University of Pharmacy, Kharkiv, Ukraine. E-mail: rukhmakovaolga@gmail.com, ORCID: 0000-0002-8573-8965

Yuryeva G. B. - PhD (Pharmacy), Associate Professor of the Technology of Drugs Department, National University of Pharmacy, Kharkiv, Ukraine. E-mail: tI@nuph.edu.ua, ORCID: 0000-0001-9719-2122. 